\title{
Courts in Semi-Democratic/Authoritarian Regimes: The Judicialization of Turkish (and Iranian) Politics
}

\author{
Hootan Shambayati
}

Turkey is not a typical authoritarian or democratic regime. For much of the past six decades Turkey has held regular multiparty and reasonably free and fair elections. Power has changed hands numerous times, and governments have come to office and left as a result of elections. Furthermore, even though the Turkish military has intervened in the political process on a number of occasions, unlike in most other developing countries, the periods of direct military rule have been relatively short (1960-1962 and 1980-1983). Finally, for much of the past half-century, Turkey has had lively social and political societies that have acted with relative freedom, although major shortcomings continue to plague both. There is much to suggest that Turkey should be classified as a democracy.

At the same time, however, it is widely recognized that the Turkish political system displays authoritarian tendencies and that the military continues to play an important role in Turkish politics. The Turkish military has formally intervened in politics on four occasions (1960, 1971, 1980, and 1997). In 1960 and 1980, the military officially assumed the reins of power, while in the other two instances it limited itself to issuing a series of ultimatums that eventually brought down the governments of the day without formally interrupting the democratic experience.

The 1960 and 1980 military coups were followed by attempts to restructure political and social life through new constitutions. The military's desire to redesign the political and social life of the polity is, of course, a common feature of many military interventions. Military interventions are frequently reactions to what officers believe to be the shortcomings of the political system and are often followed by attempts to fundamentally alter the basis of the political system. In the Turkish case, the short periods of military rule have meant that the military has had to limit itself to altering the formal rules of the game while leaving the implementation of more deep-rooted changes until 
after the return to civilian rule. Consequently, creating a constitutional setup that allowed it to continue to influence civilian politicians and intervene in the political process was one of the major goals of the military leadership in both the 1960 and the 1980 military coups.

On each occasion the military regime imposed a new constitution on the nation before formally returning power to civilian politicians. Despite some major differences in the area of rights and liberties, the military-inspired 1961 and 1982 constitutions both display the fundamental distrust of the state elite toward politics and politicians (Özbudun 2000: 53-60). As I discuss below, both constitutions recognized the legitimacy of elections and elected officials, but at the same time tried to limit the effectiveness of elected institutions by subjecting them to control by a network of unelected institutions. In the view of military officers and high-ranking bureaucrats, including many jurists, selfinterested politicians could not be trusted with serving the national interest. Accordingly, both constitutions were designed to limit the powers of the parliament and elected institutions by subjecting them to control by unelected state institutions.

In their attempts to restrict the powers of the parliament, both constitutions not only provided the military with formally recognized mechanisms to intervene in day-to-day policymaking but also empowered the judiciary to review the decisions of the parliament and the elected governments. As I discuss below, this division of sovereignty between elected and unelected institutions has contributed to the judicialization of Turkish politics and has led to the emergence of Turkish courts, particularly the Constitutional Court and the Council of State, as important political institutions that have often used their powers to counteract the parliament.

The division of sovereignty between elected and unelected institutions, of course, is not unique to Turkey and can be found in many regimes. Nor is it the function of a particular ideology. The prototype of such regimes is the Islamic Republic of Iran where the powers of the elected parliament and the president are subject to review by a web of institutions controlled by a religiously empowered Supreme Leader. As I discuss at the end of this chapter, in Iran too this political structure has contributed to the judicialization of politics.

Since the bulk of this chapter deals with the Turkish case, I begin with a brief discussion of the main characteristics of military-inspired judicial empowerments. I will argue that military regimes might be particularly interested in empowering the courts to become active in the political arena after the military's return to the barracks. I will then proceed to discuss the specifics of the Turkish political system and the role of the judiciary in Turkish politics. The final section of the chapter briefly discusses the Iranian case. 


\section{MILITARY-INSPIRED JUDICIAL EMPOWERMENT}

Both Bruce Ackerman and Tom Ginsburg have argued that judicial review is associated with weak militaries (Ackerman 1997; Ginsburg 2003: 83). A similar conclusion can be reached based on Ran Hirschl's "hegemonic preservation thesis." According to Hirschl, waning political actors will choose to empower the courts to maintain hegemony in the event they lose control of the Parliament (Hirschl 2004). While a strong military, or for that matter any other strong actor, need not rely on the courts to protect its interest while in power, a military regime might have strong incentives to empower the courts before leaving office. Furthermore, political systems based on competitive elections with unelected "guardians," such as those found in Turkey and Iran, require a network of institutions that often include the courts to control elected institutions without undermining the stature of the guardians as allegedly above politics.

The military does not face the same dilemmas faced by civilian political institutions when empowering the courts. When civilian executives and legislators create constitutional tribunals, they are creating organizations that limit their own powers. When the military empowers the judiciary it creates an institution that limits the powers of civilian institutions without necessarily affecting the position of the armed forces. First, the military's core internal concerns, such as training or promotion, are likely to be outside the competence of the civilian judicial institutions, including constitutional tribunals. In the Turkish case, for example, the 1982 Constitution forbids the civilian courts from reviewing decisions of the Supreme Military Council. ${ }^{1}$

Second, the military is not equally interested in all policy areas. The military is likely to be much more interested in security and order than in public health or price controls, for example. Not only have the courts generally accommodated security needs but also an outgoing military regime can put in place rules and regulations that are exempt from review by judicial authorities. Until its amendment in 2001, for example, the 1982 Turkish Constitution prevented the courts from reviewing the constitutionality of laws and regulations put in place by the military regime.

Third, particularly in civil law countries, the military might see the judiciary as a natural ally in the post-transition period. Like the military, the judiciary in the civil law tradition is a hierarchical organization performing a "technical" role. Judges enter the judicial service shortly after completing their legal education and spend their entire careers within the judiciary. Like military officers, judges see their role as technical and believe that they are merely

1 Article 125 . 
applying the law. Judges are trained to view law and politics as two completely distinct arenas. Furthermore, as in the military, the promotion of judicial personnel in the civil law tradition has historically been controlled by the more senior judges, producing an ideologically homogeneous institution with a strong esprit de corps that identifies strongly with the state and sees politics and politicians as divisive and corrupt. In short, the military and the judiciary might share a number of common values and assumptions about politics and politicians (Correa Sutil 1993; Galleguillos 1998; Guarnieri and Pederzoli 2002: 49; Hilbink 1999, 2001; Tate 1993).

Finally, an outgoing military regime can create constitutional tribunals and other judicial institutions that will be inclined to give the military's point of view the most favorable of hearings. Self-interested political actors adopt judicial review as an "insurance policy" to protect their interest in the event of future electoral losses (Ginsburg 2003: 25). The institutional design of the judiciary and the high courts, like those of other institutions in a democracy, depends on the relative strength and the interest of the political actors (Ginsburg 2003; Magalhaes 1999: 43; Smithey and Ishiyama 2000, 2002). Their ideal institutional design will produce judicial actors who will be partial to their interest whether they are in or out of power.

Two aspects of judicial institutions are of particular interest to political actors. First, judicial appointment procedures affect the ability of dominant political actors to appoint like-minded judges or to prevent the appointment of judges whose preferences they do not like. Second, the rules governing judicial careers and the institutions that manage those careers determine the judiciary's responsiveness to political actors. As Magalhaes, Guarnieri,and Kaminis (2007) conclude, "The control of a system of punishments and rewards associated to judicial careers (promotion, assignment, recall) ... can be used to condition judicial behavior, independently of the actual composition of courts and the policy preferences of judges."

Civilian political actors' preferred institutional design depends on their estimate of their own political prospects under the democratic regime (Magalhaes 1999; Smithey and Ishiyama 2000). In East European countries where the outgoing Communist parties expected to hold onto power by winning the upcoming free elections, they were willing to increase the oversight powers of the political branches over the judiciary. Where they expected to lose the elections, however, they tended to isolate the judiciary from the political branches. Where the incumbent rulers were uncertain of their prospects under the democratic regime, they were more likely to provide a role for the opposition in appointing judges and less likely to introduce sweeping institutional changes (Magalhaes 1999: 47-48). 
Transitions from military rule follow a similar logic. However, in these cases the picture is more complex. As a unit of the state, the military will be reincorporated into the state apparatus after the transition and can be certain of its continued participation in the state under the democratic regime. However, the military, unlike civilian authoritarian institutions such as Communist parties, cannot reorganize itself to compete in democratic elections. An outgoing military regime is an actor with no expectation of winning elected office, but certain of the military's continued influence under the new regime. As the Turkish case demonstrates, in such cases the tendency will be toward the creation of politically powerful judicial institutions to act as guardians of the military-sponsored constitutional order without directly involving the military. At the same time, however, the outgoing military regime will try to minimize the influence of the political branches in the affairs of the judiciary, including appointments to the high courts.

\section{THE TURKISH POLITICAL SYSTEM}

In 1998, when veteran politician and many times prime minister Süleyman Demirel occupied the presidential office, he was asked to comment on a growing crisis between the then-prime minister Mesut Yilmaz and the military leadership. According to published reports Demirel replied with the following story:

In an English zoo there was an experiment to have wolves and sheep live together in one cage. Someone asked the director if the experiment was working. The director replied, yes, but occasionally we have to replace the sheep (Bila 1998).

Mr. Demirel should know. As prime minister he had been removed from office by the military in 1971 and 1980; as president he had presided over the military-engineered downfall of the Islamist Welfare party government in June 1997 and the party's eventual closure by the Constitutional Court in January 1998.

As the story above suggests, Turkey is an example of what Daniel Brumberg has called "dissonant institutionalization." According to Brumberg "dissonant institutionalization occurs when competing images of political community and the symbolic systems legitimating them are reproduced in the formal and informal institutions of state and society" (Brumberg 2001: 33-34). As a consequence, systems based on dissonant institutionalization are likely to produce high levels of political tension. 
In the Turkish case, dissonant institutionalization has led to a bifurcated political system, where parts of the system aim at transforming the society, while others try to maintain the status quo. The consequence has been a high level of tension between what the Turks refer to as the State (devlet), consisting of the security establishment, the presidency, the judiciary, and parts of the civilian bureaucracy, and the government (hükümet), consisting of the elected Parliament and cabinet. The management of the resultant tensions is a fundamental concern of the political system.

At the same time, however, the system's continued survival depends on maintaining a high level of tensions between the competing institutions. While the continued coexistence of the wolves and the sheep in the same cage requires mechanisms to keep the two separate from each other, it also needs constant justification. As I have discussed elsewhere, "a regime based on divided sovereignty must prevent social and political tensions from boiling over and threatening the stability of the system, while at the same time generating enough tensions to justify the continued presence of both heads of the executive" (Shambayati 2004).

Regimes such as that found in Turkey are particularly vulnerable to societal challenges. Dissonant institutionalization is an indication that the ideological basis of the regime is weak (Brumberg 2001). In the Turkish case, the state is officially based on Kemalism. Kemalism, however, has never evolved into a full-fledged coherent ideology.

Kemalism aims at transforming society, particularly in areas such as secularism and nationalism, or, in the words of Ataturk, to bring the people to "the level of contemporary civilization." The Turkish state elites see the state and the law as mechanisms for the transformation of society and often find themselves at odds with powerful societal actors whose interests are threatened by the civilizing mission. Furthermore, as the emergence of a modernist Islamist movement and Kurdish nationalism suggests, state policies have had unintended consequences and have led to the emergence of new social and political movements that are not easily incorporated into the existing political structure. From the perspective of the state elite, including many judges, the proper function of the courts is to defend the civilizing mission against potential threats from society, even if at times that means acting against the will of the nation as expressed through elections.

Dissonant institutionalization also contributes to judicialization at another level. As the story of the wolves and the lambs demonstrates, the division of

2 This oft-repeated phrase is from a speech delivered by Ataturk on the Occasion of the Tenth Anniversary of the Foundation of the Turkish Republic (29 October 1933). See http://www.allaboutturkey.com/ata_speech.htm 
sovereignty between elected and unelected executives is public and formally sanctioned. Both the Constitutions of 1961 and 1982 and other laws provided for a military-dominated National Security Council as an important part of the decision-making process and gave the military considerable power in the formulation and implementation of policies through a variety of nonpolitical regulatory and supervisory boards, such as the Higher Education Board and the Board of Radio and Television. The Turkish military is not merely the "guardian of the system," but is an active participant in the political decisionmaking process.

Nor is the military shy about its political role. In fact, suggestions that the military might not be interested in a given political issue are often met with a statement from the high command denying the lack of interest. For example, a few months prior to the selection of a new president by the Parliament in 2000, the chief of the general staff declared that it was "inconceivable that the military would not have an opinion on who will be the next president" (Hürriyet, 15 April 2000). Similarly, in 2003 when a meeting between the Commander of the Land Forces and a group of university rectors who opposed a government proposal to reform the Higher Education Board and the university entrance requirements caused a public controversy, the general staff circulated a formal statement that read "it is natural that developments pertaining to the national education system, which is of vital importance for Turkey, are followed by the General Staff" (Turkish Daily News, September 16, 2003)

Furthermore, the military's role is accepted as legitimate by a large segment of the political leadership and the public in general. For example, the military statements quoted above were immediately justified by the political leadership as "natural." In the first instance, as the then-prime minister Bülent Ecevit put it, "it is only natural that the military will be interested in these elections especially when the president is also the commander in chief of the armed forces and the head of the National Security Council" (Turkish Daily News, 16 April 2000). Similarly, the main opposition party (the Republican People's Party) characterized the rectors' meeting with the generals "as very normal" (Turkish Daily News, 16 September 2003)

Despite its influence, the fact that the military has to share power with popularly elected politicians means that it can only be effective if it can maintain its above-politics stature in public's mind. The framers of the Turkish constitutions tried to achieve this objective by transferring potentially contentious policy debates away from the Parliament and entrusting them to the so-called neutral institutions such as courts. As Haggard and Kaufman have argued, regimes with guardians create "insulated decision-making structures that can be counted on to pursue [the guardian's] policy agenda” (Haggard and Kaufman 1995: 121). 


\section{Judicial Empowerment in Turkey}

The empowerment of the judiciary in Turkey dates back to the militaryinspired Constitution of 1961, when "the judiciary was given a considerable share in the exercise of sovereignty" (Aybay 1977: 24). This so-called liberal constitution was a reaction to what many believed to have been serious abuses of political power by the elected Democratic Party governments (1950-1960) that had necessitated the 1960 military intervention. Like their counterparts in some other developing countries, the Turkish military turned to the legal community to legitimate the military intervention. As Rona Aybay notes, "one of the most interesting aspect of the May 27 [1960] coup is its legalistic tendency" (Aybay 1977: 21). Within hours after the coup the junta asked for and received the endorsement of a group of law professors who issued a rather lengthy statement in support of the coup. The statement in part read as follows:

It is not right to regard the situation in which we find ourselves today as an ordinary political coup d'Ettat. The political power which should represent the conception of State, law, justice, morality, public interest and public service and should protect public interests had for months, even years, lost this character, and had become a material force representing personal power and ambition and class interests.

The power of the State, which before all else should be a social power bound by law, was transformed into an instrument of this ambition and power. For this reason this political power lost all its moral ties with its army ... with its courts and the bar, with its officials who wanted to be loyal to their duties, with its universities, and with its press which represents public opinion, and with all its other social institutions and forces, and fell into a position hostile to the State's genuine and main institutions, and to Ataturk's reforms, which are of extraordinary value and importance if Turkey is to occupy a worthy place among the nations of the world as a civilized State (cited in Ahmad 1977: 162-163).

The experiences of the 1950 and the coup had convinced the military leadership and their civilian allies that the new constitutional structure should impose limits on the powers of the Parliament and prevent any single party from dominating the government. To meet this requirement, the 1961 Constitution adopted a new concept of sovereignty. Article 4 of the Constitution declared,

Sovereignty is vested in the nation without reservation and condition. The nation shall exercise its sovereignty through the authorized agencies as prescribed by the principles laid down in the Constitution. 
These words were repeated in article 6 of the 1982 Constitution and, as the official history of the Constitutional Court interprets them, were meant, "to put an end to the principle of the supremacy of the parliament."3

The ${ }_{1961}$ Constitution took two steps to operationalize this provision. First, it increased the internal autonomy of some institutions such as universities and the radio and television authority and imposed severe limits on the ability of the Parliament to interfere in their internal affairs. Similarly, in an attempt to increase the independence of the judiciary, the newly established Supreme Council of Judges was given the responsibility to administer all judicial personnel matters (Devereux 1965). Furthermore, to further protect the autonomy of the universities and the judiciary, the constitution authorized the two institutions to petition the Turkish Constitutional Court (TCC), another new institution, in matters relating to their own functions.

Second, the 1961 Constitution divided sovereignty among a number of newly created institutions. Chief among these was the newly established National Security Council, which for the first time provided a formal venue for military participation in political decisions. In the judicial arena, the constitution enhanced the powers of the Council of State, an administrative court dating back to the Ottoman era and modeled after the French conseil d'etat, and created a Constitutional Court.

The establishment of the Constitutional Court was achieved with little controversy. The idea for a constitutional court with the power to review the constitutionality of legislative acts was first proposed in the mid-1950s by the Republican People's Party (RPP; McCally 1956), which as the main opposition party suffered the most under Democratic Party rule, and had little difficulty in passing through the RPP-dominated constituent assembly (Kili 1971: 139). Modeled after continental European constitutional courts, the Constitutional Court "was expected to counterbalance political institutions, especially the parliament, which would abuse their powers."

The 1961 Constitution was "a last-ditch effort by the bureaucratic intelligentsia to set the substantive, as well as the procedural, rules of the political game in Turkey" (Heper 1985: 89). It tried to enhance the autonomy of the state by protecting it against interest-based politics. Although it granted the right of political participation, it also created bureaucratically staffed agencies to act as watchdogs over political institutions. Accordingly, in their structures and powers the TCC and other judicial organs reflected a constitutional design

3 These words had originally appeared in a 1977 article by Rona Aybay (Aybay 1977: 23) and were repeated without attribution on the TCC's Web site.

4 Official Web page. 
that assumed a fundamental "mistrust of the organs dependent upon universal suffrage" (Aybay 1977: 24).

The consequence has been that the Turkish courts have not shied away from challenging the Parliament and elected officials. Between 1962 and 1980 the TCC reviewed 350 petitions for abstract review and annulled 37 percent of them (Shambayati 2008). In its attempts to the "tame the Parliament" the TCC was joined by the Council of State, which annulled 1,400 governmental decrees between 1965 and 1971 (Heper 1985: 92). The hyperactivity of the courts in the pre-1980 period led to charges that the courts were making it impossible for the governments of the day to govern and undoubtedly contributed to the political tensions and instability that finally resulted in the September 12, 1982, military takeover (Ahmad 1977; Dodd 1983).

Once again the period of direct military takeover was short, and power was returned to elected civilian officials within three years. Again, the military tried to restructure political and social life by introducing a new constitution. In the rising political polarization of the 1960s and the 1970s the internal autonomy of the universities and other institutions proved destabilizing, and the 1982 Constitution reversed the trend. This, however, did not result in an increase in the powers of the Parliament. Instead the 1982 Constitution relied on a number of so-called "neutral" institutions and commissions such as the Higher Education Board to administer the previously autonomous institutions. 5 A common feature of these institutions is that until the recent EU-inspired reforms they included a military representative on their boards.

The 1982 Constitution not only maintained the division of sovereignty introduced in 1961, but further limited the powers of the Parliament by stripping it of its appointment powers and transferring them to the president, an indirectly elected nonpartisan figure. This enhancement of presidential powers was designed to increase the military's influence. Under the new constitution, the leader of the military junta, General Evren, automatically assumed the presidency upon its formal adoption. ${ }^{6}$ Furthermore, the framers hoped that the pre-coup practice of the Parliament choosing a retired military officer for the presidency would continue. Although of the four men who have occupied the office since 1983, Evren is the only one with a military background, the presidency, particularly under its current occupant Ahmet Necdet Sezer, a former president of the TCC, continues to be identified with the state and

5 This controversial body is charged with supervising universities and was first introduced in the 1970s, but was ruled unconstitutional by the Constitutional Court because it violated the constitutionally guaranteed principle of the autonomy of the universities. It was given constitutional status in the 1982 Constitution.

6 Provisional Article 1. 
acts as a brake on the powers of the Parliament. As the next section shows, the changes in the powers of the president were also designed to reduce the influence of the Parliament over the judiciary.

\section{The Judiciary After 1982}

The 1982 Constitution maintained the basic division of sovereignty introduced by its predecessor and further enhanced the role of nonelected institutions in the decision-making process. The earlier constitution had relied on a number of institutions in which members appointed by the Parliament and those appointed by the various state agencies jointly exercised power. This cooperative structure, however, proved unsatisfactory as political tensions and violence continued to increase in the 1960 and the 1970 . Therefore, the 1982 Constitution abandoned the cooperative framework in support of a new structure that sharply reduced the role of the Parliament in determining the membership of the so-called neutral institutions and boards while increasing the role of state institutions. The most dramatic example was the National Security Council whose powers were greatly enhanced and in which the number of military members was increased at the expense of the civilian wing. ${ }^{7}$

A similar design was introduced for judicial institutions. Table 11.1 shows the appointment procedures for various judicial institutions. Under the 1961 Constitution the two houses of parliament appointed one-third of the members of the Supreme Council of Judges and Public Prosecutors and one-third of the justices of the Constitutional Court. The 1982 Constitution, however, under the guise of protecting the independence of the courts completely eliminated the role of the Parliament as either a nominating or an appointing body. ${ }^{8}$

Similarly, the 1982 Constitution reduced the number of judges on the Constitutional Court and drastically altered the appointment procedure. Under the original design, the Parliament appointed five of the justices while the other high courts and the president appointed the other ten permanent justices. Under the system in place since 1982, the Parliament and the cabinet have no role in the appointment process. Instead, the courts are the nominating bodies in the current system, while the president appoints all justices. For each seat the appropriate court submits a list of three candidates drawn from among its own justices and prosecutors to the president, who makes the final

7 A series of constitutional amendments adopted since 2001 have increased the number of civilian members of the NSC in an attempt to "civilianize" the organization.

8 The Minister of Justice and his deputy take part in the meetings of the council in an ex officio capacity. 
TABLE 11.1 Judicial appointment procedures

\begin{tabular}{lll}
\hline \hline Institution & 1961 Constitution & 1982 Constitution \\
\hline Constitutional Court & Permanent 15 & Permanent 11 \\
& Substitute $(5)$ & Substitute $(4)$ \\
Court of Cassation & $4(2)$ & $2(2)$ nomination \\
Council of State & $3(1)$ & $2(1)$ nomination \\
Court of Accounts & 1 & 1 nomination \\
Military Court Cassation & & 1 nomination \\
Military Admin. Court & & 1 nomination \\
Higher Ed Council & $3^{*}(1)$ & 1 nomination \\
Nat'l Assembly & $2^{*}(1)$ & 0 \\
Senate & $2^{* *}$ & NA \\
President & Permanent 18 & $11(4)$ \\
Supreme Council of & Substitute $(5)$ & Permanent 6 \\
$\quad$ Judges & $6(2)$ & $3(3)$ nomination \\
Court of Cassation & $6(1)$ & \\
Judges of 1st rank & $3(1)$ & \\
Nat'l Assembly & $3(1)$ & $3 / 4$ of members \\
Senate & 0 & $6(5)$ \\
Council of State & 0 & \\
President & & \\
Council of State & All members & \\
Constitutional Court & & \\
Supreme Council of Judges & & \\
President & & \\
\hline
\end{tabular}

* One has to be a member of the teaching staff of the departments of law, economics, or political science.

** One had to be a member of the Military Court of Cassation.

Figures in italics are nominations.

appointment. Finally, under the 1982 Constitution the military courts nominate two of the permanent justices of the TCC, a provision that is reminiscent of the Chilean Constitutional Tribunal in which the national security council appoints two of the justices.

The military was also given a role in the administration of justice through the controversial State Security Courts. The establishment of these courts had been a long-term military objective dating back to the coup by the memorandum of March 12, 1971 (Hale 1977: 187). They were established in 1973 through a constitutional amendment and special legislation to deal with the increasing political violence coming from both the right and the left of the 
political spectrum. In 1975, the Constitutional Court, acting on a petition from the Diyarbakir State Security Court, ruled that the tribunals were unconstitutional and ordered their closure. 9 The abolishment of these courts was given as a reason by the leaders of the 1980 coup as to why the 1961 Constitution was inadequate.

The framers of the 1982 Constitution revived the State Security Courts to deal with a wide range of crimes. Unlike ordinary courts, these courts were presided over by a panel of three judges, one of whom was a military judge appointed by the military courts. The Supreme Council of Judges and Public Prosecutors appointed the civilian judges and prosecutors. Until their final abolition in 2004 under pressure from the European Union and human rights organizations, these courts were one of the mainstays of the Turkish judicial system and used special procedures to try a wide range of crimes ranging from reciting politically provocative poetry ${ }^{10}$ to acts of terrorism. Both their composition and their procedures were found to be in violation of numerous provisions of the European Convention on Human Rights and led to many rulings against Turkey by the European Court of Human Rights. At the same time, however, in the words of one prosecutor, they also "prevented many military coups" by satisfying the military's demands for harsh punishments for those accused of violating state security laws (Turkish Daily News February 20, 2001). Other judicial institutions have also contributed to fulfilling this function of the courts. As I discuss in the next section, the Constitutional Court and the Council of State have been particularly important in preventing direct military interventions. Through their rulings and public pronouncements both institutions have become important actors in the political arena.

\section{The Courts in Action}

The high wall between the judiciary and elected institutions erected by the 1982 Constitution and the judiciary's belief that it has a share in the exercise of sovereignty have turned Turkey into one of the most judicialized polities to be found in the modern world. On average the Constitutional Court issues a judgment for annulment in 76 percent of the cases that it receives for abstract review. As in other countries with abstract review procedures, most petitions for review are made by the opposition party, although Turkey's current president

9 Although the original petition was partially based on the principle of the unconstitutionality of extraordinary tribunals, the TCC based its decision on procedural grounds.

10 This was the charge against Turkey's current Prime Minister Recep Tayyip Erdogan, who served four months in jail after being convicted by the Diyarbakir State Security Court in 1999 (see Shambayati 2004). 
Ahmet Necdet Sezer, himself a former president of the Constitutional Court, has also been very active in sending legislative acts to the TCC for review (Hazama 1996; Shambayati 2007).

The high success rate of the abstract review petitions is no doubt in part due to the fact that many provisions of the 1982 Constitution are no longer applicable to today's Turkey. Furthermore, both the process of integration with the EU and the privatization of the economy have required economic and political reforms that were not foreseen by the framers of the constitution. "Radical reforms," as Stone Sweet notes, "strain or tear the web of existing legal regimes, administrative practices, and case law" (Stone Sweet 2000: 52). Radical reforms, by definition, create tensions in the society and encourage an appeal to the courts. The law and the judiciary, however, are reactionary institutions that do not welcome reforms easily (di Federico and Guarnieri 1988: 168; Stone Sweet 1992: 39).

At the same time, however, the frequent rulings against the Parliament also point to a fundamental distrust between elected and unelected institutions inherent in the Turkish system. The distrust between the judiciary and politicians is evident not only in the frequent rulings of the Constitutional Court against the Parliament but also in its frequent public warnings to the ruling governments of the day not to violate the basic principles of Kemalism, particularly when it comes to secularism and national unity. Since the election of the Islamist Justice and Development Party (AKP) in 2002, for example, high-level justices have repeatedly warned the government not to try to lift the ban on the wearing of headscarves in the universities, an issue that is very important to the party's supporters. The strongest warning came from the president of the TCC in 2005, who used the anniversary of the Court's founding to warn the government that changing the law would be unconstitutional and that even a constitutional amendment would not suffice. He went on to remind the government that the Court has closed other political parties for violating the principles of secularism ${ }^{11}$ (Hürriyet April 24, 2005). In effect, the president of the TCC was reminding the government that in a "militant democracy" like Turkey, the courts sometimes go beyond the text of the constitution to protect the regime.

An important aspect of protecting the Turkish democracy has been the frequent closure of political parties (Arslan 2002; Koçak and Örücü 2003; Kogacioglu 2003, 2004). Since 1983, the TCC has closed eighteen political

11 This, of course, was a reference to the fate of the Justice and Development Party's predecessor, the Welfare Party, which was forced from office by the military in June 1997 and closed by the Court in January 1998. 
parties. The Court has been particularly tough on Islamist and pro-Kurdish parties and has accused them of undermining secularism and the unity of the country. In closing these parties, as Dicle Kogacioglu has argued, the court has been participating "in shaping the boundaries as well as the content of the political process" (Kogacioglu 2004: 459).

The Constitutional Court is not alone in this task. Other courts, too, often use their powers to shape the content of politics. An example is a controversial ruling by the Council of State in October 2005 that argued that a kindergarten teacher could not be promoted because she wore a headscarf on her way to work. Although there are no laws that ban the wearing of the Islamic headscarf in public and the court recognized that the teacher in question had abided by the current regulations that forbid the wearing of headscarves in schools and government offices, it nevertheless argued that promoting her would set a bad example for the children in her charge and could undermine the secular basis of the state. Behind the Council's decision was, of course, the secular establishment's concern that the ruling AK party was systematically promoting its supporters into positions of influence in the state bureaucracy and was relaxing state regulations on religious practices.

This ruling caused a mini-crisis in Turkish politics when, in May 2006, a lawyer with ties to Islamist circles opened fire in one of the Council chambers, killing one of the justices and wounding four others. The shooting was greeted with much apprehension in Turkey, and both civilian and military leaders rushed to support the Council of State to show their solidarity with the judiciary. The president of the Council issued a statement that criticized the government's policies on secularism, blamed the attack on the government's criticism of the Council's original decision, and portrayed the attack as an attack on the secular state. The next day, large demonstrations were organized at Ataturk's mausoleum where representatives of various segments of the society including the political parties and the military gathered to defend the secular basis of the state. Public statements issued by the military, the president, and various judicial bodies emphasized the need to stay vigilant against religious reactionaries and pointed the finger at the ruling Islamist Justice and Development Party.

This tragic and inexcusable attack points to one of the shortcomings of attempts to resolve political differences through court rulings. Despite numerous rulings by the Council of State, the Constitutional Court, and the European Court of Human Rights, all of which have upheld the provisions banning headscarves in universities and state offices, the issue continues to play a prominent role in Turkish politics. Religious and center-right parties, particularly when in opposition, have repeatedly used the issue to rally their supporters. On 
the other hand, the secular establishment and center-left parties have continuously presented these campaign promises as evidence of disregard for the rule of law and as threats to secularism, hence justifying the continued vigilance of the military and the judiciary in protecting the "civilizing mission" of the state.

Similarly, the closing of numerous political parties, cultural associations, and publications and the frequent jailing of political activists have only had limited success in eliminating social and political movements that challenge the ideology of the state. Closed political parties, particularly those with Islamist or pro-Kurdish social bases, quickly reorganize and appear under a new banner to challenge the boundaries imposed by the state. The continued survival of these movements, and in the case of Islamist and pro-Kurdish political parties their ability to win elections, in turn is used to justify the need to vigilantly protect the civilizing mission of the state.

Even when the courts have ruled against the state, and there are many such instances, the rulings have tended to legitimate the continued division of sovereignty. In the mid-199os, for example, when a number of prominent secular intellectuals were assassinated or attacked by terrorists with links to fundamentalist religious circles, the Council of State ruled that the state had failed to provide adequate protection to the individuals involved and therefore was liable (Orucu 2000: 694). Although on the face of it these rulings were victories against the state, they, of course, underlined the continued threat to secularism and the inability of the elected governments to deal with it.

In short, in Turkey's bifurcated political system the courts play an important role in protecting the civilizing mission of the state and maintaining the division of sovereignty between elected and unelected institutions. As the brief discussion of the Iranian case in the next section demonstrates, this situation is not unique to Turkey and is a function of the dissonant institutionalization in the political system rather than any particular ideology.

\section{COURTS IN THE ISLAMIC REPUBLIC OF IRAN}

The Iranian constitution of 1979 recognizes God as the only legitimate source of sovereignty. ${ }^{12}$ Nevertheless, the dynamics of a mass revolution and the pluralism of the Shia political thought and religious establishment meant that the framers of the constitution also had to recognize the people as a source of sovereignty (Chehabi 2001). Accordingly, the constitution created a number of elected institutions, including a Parliament and a president. As in

12 Article 56. 
Turkey, however, the power of the elected institutions is subject to supervision by unelected institutions. Whereas in Turkey this supervisory role is played by the military, in Iran it is the Supreme Leader who as the highest religiopolitical authority supervises all institutions of the state, including the Parliament and the presidency. ${ }^{13}$ While the Parliament and the president represent the will of the nation as expressed through elections, the Supreme Leader draws his legitimacy from representing the sovereignty of God based on the doctrine of the guardianship of the jurisprudent (velayat-i faqih). The Iranian political structure hence is based on competing notions of sovereignty and includes institutions that are often at odds with each other (Brumberg 2001; Buchta 2000). Consequently, high levels of tension are endemic in the Iranian political system.

Similar to Turkey, the Iranian political system relies on a number of extrapolitical and semi-judicial institutions to manage the tensions created by "dissonant institutionalization." The most important actor in this regard is, of course, the Supreme Leader himself, who is the final arbiter in all disputes. The Supreme Leader, however, like the military in Turkey, can only play this role if he can publicly maintain an above-politics posture. Consequently, the Supreme Leader relies on a complex web of institutions to control elected institutions. Courts and court-like institutions are an integral part of this system and play an important role in both managing and maintaining the tension-ridden political structure.

Iran does not have a proper mechanism for constitutional review. The initial attempts to establish a constitutional court based on the French Constitutional Council were rejected in favor of a system unique to Iran. In the Iranian system the power to review the constitutionality of legislative acts belongs to the Council of Guardians. The Council of Guardians is simultaneously an upper legislative house, a constitutional council controlling the constitutionality of laws, and a religious assembly vetting un-Islamic ordinances and candidates. As the upper house of the Parliament, the Council has to approve all pieces of legislations before they can become law. In reviewing legislation, however, the council does not limit itself to political considerations, but also makes a final decision on the constitutionality of proposed acts. The constitution further instructs the Council to also assure that all legislation meets requirements prescribed by religious law. ${ }^{14}$ In addition to these functions, the Council also

13 Technically, the Supreme Leader is an indirectly elected official, since a popularly elected Assembly of Experts, consisting of religiously qualified members of the clergy, selects him. He is, however, completely unaccountable and serves for life.

14 Article 91. 
has the controversial duty to determine the qualifications of the candidates for the various elections in the Islamic Republic, including those for the presidency and the Parliament.

The structure of the Council and its procedures ensure that it closely follows the ideological line established by the Supreme Leader. Six members of the Council are religious scholars directly appointed by the Supreme Leader. The Council also includes six nonclerical members selected by the Parliament. However, the Parliament's role in determining the composition of the Council is limited by the constitutional requirement that the Head of the Judiciary, an official appointed by the Supreme Leader, nominates the candidates. On matters concerning constitutionality, all twelve members take part in decisions, but the support of three-fourths of the members of the Council is required for a ruling on the constitutionality of legislative acts. In other words, at least three clerical members must support a decision on constitutionality. Only the six clerical members, on the other hand, conduct reviews based on Islamic law, and those decisions are made by a simple majority. ${ }^{15}$

Through the Council, the conservative factions within the Islamic Republic were able to stop the reformist government of President Mohammad Khatami from adopting many of its reform proposals. Between 1997 and 2005, the council rejected 37 percent of the laws adopted by the Parliament and disqualified scores of reformist candidates from standing in various elections, including those for the Parliament and the presidency (Secor 2005: 64).

The tensions in the Iranian political system are not limited to ideological differences between reformists and more conservative factions. They are an integral part of the system and are caused by the structure of the Islamic Republic. Soon after the establishment of the Islamic Republic, it became clear that the tensions between the Parliament and the Council of Guardians, and more generally between elected and unelected institutions, had the potential of paralyzing the political system. This realization led to the creation of another constitutional body, the Expediency Council.

The Supreme Leader appoints all members of the Expediency Council. In addition to the heads of the three branches of the government (the Speaker of the Parliament, the President, and the Head of the Judiciary), the council also includes the six clerical members of the Council of Guardians and other personalities of the regime appointed by the Supreme Leader. As the composition of the Expediency Council suggests, it is a forum for joint policymaking by elected and unelected institutions. Its main function is to arbitrate differences between the Parliament and the Council of Guardians and to establish the

\footnotetext{
15 Iranian Constitution, Articles 91-99.
} 
overall policies of the Islamic Republic. Its formation was a recognition of the high levels of tension endemic in the political system.

This system is complemented by a heavy reliance on courts and the judiciary. The Iranian judiciary is set up as a separate bureaucracy attached to the office of the Supreme Leader. The head of the judicial branch is directly appointed by the Supreme Leader and answers to him, rather than to the elected president or the Parliament. The head of the judiciary is responsible for the appointment of all judges and even nominates the Minister of Justice, who is a member of the president's cabinet. Furthermore, the Head of the Judiciary is an active participant in the policymaking process. He not only nominates the nonclerical members of the Guardian Council but he is also a member of both the Expediency Council and the National Security Council.

Despite constitutional guarantees of judicial independence, the Iranian judiciary is designed as a political institution that is responsible not only for the administration of justice but also for the implementation of the ideologi$\mathrm{cal} /$ political line advocated by the Supreme Leader. The judiciary carries out its multiple functions through a complex system that relies heavily on specialized courts, such as the Press Court, responsible for matters related to the media, and the Special Court for the Clergy.

The judiciary emerged as an important political player during the presidency of Khatami (1997-2005). With the unexpected election of Khatami and the emergence of the reform movement as a viable political alternative, tensions in the Iranian political structure reached a new peak. As Eric Rouleau notes, "The cohabitation between the faqih Ayatollah Khamenei, the supreme politico-religious authority, and President Mohammad Khatami [came] to resemble a multi-faceted guerrilla war" (Rouleau 1999). Having lost at the ballot box, the conservatives, like their Turkish counterparts, relied on the courts to contain the reform movement.

During Khatami's tenure in office, political trials targeting his supporters became common, and dozens of politicians, activists, journalists, and intellectuals were convicted of a range of political crimes. In addition, the Press Court systematically closed many reformist newspapers (Khiabani and Sreberny 2001). Although the accused were often charged with undermining the regime, many of them were "children of the revolution" who not only had participated in the revolution but also had held high governmental positions in the Islamic Republic. Furthermore, the objective of these trials was not to punish the individual culprit, so much as to stop the political movement of the reformers. ${ }^{16}$

16 See for example the remarks of journalist Akbar Ganji, one of the leading ideologues of the reform movement who was himself convicted for his writings, cited in Khiabani and Sreberny (2001: 206). 
The press trials and the judicial crackdown on the reform movement closely resemble the activities of the Turkish courts, which have often used their powers to ban political parties and shut down civil associations and media outlets. Fighting social movements through the courts, however, has not always been effective. Many of the banned Turkish political parties, for examples, have often reappeared and shown themselves capable of winning elections. Turkey's present ruling party, the Justice and Development Party, emerged from the ashes of the banned Virtue Party. Virtue itself was the successor to the banned Welfare Party (banned by the TCC in 1998) that had succeeded the National Salvation Party (banned after the 1980 coup), which in turn was formed after the TCC had banned the National Order Party in 1971. Similarly, in Iran, banned newspapers often reappeared with a new title but with the same journalists and editors (Khiabani and Sreberny 2001). As the Iranian dissident Akbar Ganji notes, "In political crimes the court decision is not binding, if it is not accepted as binding by the people" (Ganji 2000: 80).

\section{CONCLUSION}

Despite their diametrically opposed ideologies, one being secular and proWestern and the other theocratic and anti-Western, the Republic of Turkey and the Islamic Republic of Iran have remarkably similar political structures. Institutionally, both regimes are a mixture of democratic and authoritarian regime types. Whereas in Turkey, republican institutions, led by the military and the judiciary, compete with democratically elected institutions, in Iran it is the religious establishment and the Supreme Leader who oversee the elected Parliament and the president. As Volpi notes, "In organizational terms there is little that separates a body of religious overseers from a body of secular republican overseers" (Volpi 2004: 1071). What the two countries have in common is a bifurcated political system in which unelected institutions pursuing a civilizing mission share power with elected institutions that must be sensitive to existing societal interests.

Both the Turkish state and its Iranian counterpart pursue civilizing missions that aim to create new societies based on an ideology defined by the state elite. Since the creation of the Turkish Republic in 1923, the state has pursued a policy aimed at creating a secular and Westernized society. Similarly, the Islamic Revolution in Iran brought to power religious elites who rejected the existing society in favor of a utopian Islamic society ruled as a theocracy. In both countries, however, the state elites' vision of the future is not shared by important and powerful sectors. Consequently, even though the state elites have at least partially accepted the notion of popular sovereignty based on 
universal adult suffrage, they have created an institutional setup designed to defend the civilizing mission against its potential internal enemies. The hard-line secularists in Turkey and their religious counterparts in Iran share a common distrust of elected institutions that is reproduced in their respective political structures.

Whether one sees the cohabitation of elected and unelected institutions as the cohabitation of the "wolf and the sheep" or as "guerilla warfare," it is clear that in both countries the political system is tension ridden. Despite their enormous powers neither the Turkish military nor the Iranian Supreme Leader can guarantee the outcome of elections or the policymaking process. To manage the resultant tensions, such political systems empower so-called neutral institutions such as courts. The courts in these countries however, are not "impartial actors." Rather, their powers emanate from their partiality in favor of the state's civilizing mission and the continued domination of the political system by the unelected institutions. 